\title{
Stigma in Nursing Students towards Patients with Mental Illness
}

\author{
Rania Rabie El-Etreby ${ }^{1}$, Adel Al- Wehedy Ibrahim², \\ Mohamed Mahmoud Shahda ${ }^{3}$ \\ '(lecturer, Psychiatric and Mental Health Nursing, Faculty of Nursing, Mansoura University) \\ 2(professor, Public Health Department, Faculty of Medicine, Mansoura University) \\ 3(professor, Psychiatric Medicine, Faculty of Medicine, Mansoura University)
}

\begin{abstract}
Stigma towards patients with mental disease is a worldwide and multifaceted phenomenon and there is support that stigma and discrimination are also prevalent among health care team and health care students. Aim: to assess stigma toward patients with mental illness among undergraduate nursing students. Methods: Descriptive research design was used in this study. The sample consists of 309 nursing students in the academic year 2015- 2016 they were chosen by systematic random sampling using official students' listing. Tools: the data collected by the following tools, 1) socio- demographic characteristics of the students 2) DevaluationDiscrimination Scale, 3) Social Distance Scale, 4) Perceptions of Stigmatization by Others for Seeking Help and 5) Self-Stigma of Seeking Help. Results: The percentage of items showing signs of discrimination of mental patients like "I would eagerly believe a previous mental patient as my friend". Also large numbers of the students are" unwilling to accept mental patients as a close friend". Conclusion: The present study revealed that stigma is common among nursing students; also the results showed that there is no difference in stigma toward patients with mental illness among nursing students in the different grades.
\end{abstract}

Keywords: Stigma, Discrimination, Nursing Students, Mental Illnesses

\section{Introduction}

Mental illness is viewed to be the major cause of global disability. About $25 \%$ of all people are found to be affected by mental and behavioral disorders at some time during their lives. Stigma as a concept includes the sense of shame that lead to secrecy, which make a barrier in early diagnosis and treatment of mental illnesses. In addition, stigma tends to affect the social relationship, education, the work and other community opportunities. Moreover, it can lead to social isolation, social exclusion and discrimination ${ }^{[1 \& 2]}$.

Stigma has been described through; interpersonal interactions domain in which the major discriminating experience as reported by the mentally ill was the contact with the mental health professionals. In addition, the family members of the mentally ill expressed that mental health professionals did not appreciate their competence or experience in dealing with patients. In the second domain, structures discrimination, lack of support by the community services, lack of co-ordination, and no clear allocation of psychiatric responsibilities within mental health care as well as exclusion from the treatment process are the strongest form of this domain $^{[3]}$

Stigma towards patients with mental illness comes from not only the general public, but also from mental health professionals, it could be expected that professionals within the health care system would have a more knowledge-based, reflected and realistic view of persons with mental health problems. The health care professionals share the general public attitude towards patients with mental illness ${ }^{[4 \& 5] \text {. }}$

Previous research found that mental health professionals were less optimistic about prognosis and longterm outcome when compared with the general public ${ }^{[6]}$.Also, many studies show that nursing students have the same misconception as the public, they expecting mentally ill patients to be hostile, violent and likely to injure them. In a study measuring stigma towards mentally ill patients as perceived by nursing students it was found that nursing students reported high level of stigmatizing attitudes including assumption of dangerousness, unpredictability and a need for social distance ${ }^{[5 \& 7] .}$

Stigma appears within the nursing students due to lack of knowledge, adopting negative attitudes and avoiding patients with psychiatric illness. If nursing education does not deal with stigma, it is likely that nursing students and later on nurses will hold the same stigmatizing attitudes as have been found in the general public, including beliefs that persons with mental illness are not only in control of their illness but they caused it ${ }^{[8]}$.

So it proposed that nursing education can positively control these attitudes. Once student nurses have finished their mental health nursing course experiences, many of them express positive shifts in stigma towards persons with mental illnesses ${ }^{[9]}$.

Aim of the Research:

This research aimed to assess stigma toward patients with mental illness among undergraduate nursing students. 
Research Question:

Is there a difference in stigma toward patients with mental illness among nursing students in different grads?

\section{Subjects And Methods}

Research Design: Descriptive research design.

Setting: The current study was carried out at the Faculty of Nursing, Mansoura University, Egypt. The Faculty has eight unlike scientific nursing departments, among which is the psychiatric and mental health nursing department.

Subjects: The subjects of the study included nursing students in the academic year 2015-2016. Their total number amounted to 309 students; 82 for the first grade, 97 for the second grade, 56 for the third grade and 74 for the fourth grade. They were chosen by systematic random sampling using official students' listing. The sample size was calculated through the following formula ${ }^{[10]}$.

As:

$$
n=[\mathrm{DEFF} * \mathrm{~Np}(1-\mathrm{p})] /\left[\left(\mathbf{d}^{2} / \mathbf{Z}^{2}{ }_{1-\mathrm{a} / 2}^{*}(\mathrm{~N}-1)+\mathbf{p}^{*}(1-\mathrm{p})\right]=\ldots \ldots\right.
$$

Population size (for finite population correction factor) $(N)$ :

Hypothesized $\%$ frequency of outcome factor in the population $(\mathrm{p}): \quad 50 \%+/-5$

Confidence limits as \% of 100 (absolute +/- \%) (d): $5 \%$

Design effect (for cluster surveys-DEFF): 1

\section{Data Collection Tools:}

Five different tools were used for data collection.

Tool 1: Socio-demographic characteristics of the students such as age, sex, residence and socio economic status evaluation ${ }^{[11]}$.

Tool 2: Devaluation-Discrimination Scale: It was used to assess backing of matter thoughtful of perceived prejudiced behaviors of persons with psychiatric illness. It consists of 12 points, half of which are reverse scored. Responses are calculated on a 5-point scale ranging from 1 (not at all) to 5 (a great deal) devaluation and discrimination scale was reported to be valid and reliable, with Cronbach's alpha $=0.76^{[12]}$.

Tool 3: Social Distance Scale: This scale assesses respondents' readiness to recognize psychiatric ill patients in a variety of roles as "a property-owner; as a neighbor". Also the scale asks for self- report accounts of how a member might relate with a psychiatric ill patient. Like "How will you feel about renting a room to psychiatric ill patient?" and "How will you feel about having a mentally ill patient to be your neighbor?". SDS consists of 7 points and uses a 4-point scale ranging from 1(definitely unwilling) to 4 (definitely willing). This scale is valid and reliable with Cronbach's alpha $=0.76^{[13]}$.

Tool 4: Perceptions of Stigmatization by Others for Seeking Help (PSOSH): This scale assesses the stigma linked with how participants will cognitively react to others for seeking help for a psychiatric illness (e.g., "think bad things of them"). It consists of 5 items with a 5-point Likert-type scale ranging from 1(not at all) to 5 (a great deal). Scores are summed so that higher scores represent greater stigma. PSOSH is a valid and reliable with Cronbach's alpha $=0.78^{[14]}$.

Tool 5: Self-Stigma of Seeking Help (SSOSH): This scale assesses the stigma linked with how participants will perceive others' character for looking for help for a psychiatric illness. It has 10-items and 5point likert-type scale ranging from 1 (strongly disagree) to 5 (strongly agree). Items 2, 4, 5, 7, and 9 are reverse-scored so that higher scores reveal high stigma. It is a valid and reliable scale with Cronbach's alpha = $0.86^{[15]}$

\section{Methods of data collection:}

Official permission was obtained from the responsible authorities of the Faculty of Nursing, Mansoura University, Egypt to carry out the study. Study tools were translated into Arabic language and they were tested for their content validity by a jury of 5 experts in the psychiatric medical and nursing field and proved to be valid. Pilot study was carried out on 15 nursing students from each grade in order to test the reliability, clarity and applicability of the study tools and it was revealed that tools were clear and applicable and their (Cronbach's alpha $=0.80,0.82,0.89$, and 0.90 respectively).

\section{Ethical considerations:}

- Ethical consideration was obtained from the Research Ethics Committee of the Faculty of Nursing, Mansoura University, Egypt.

- Verbal informed consent to voluntary participate in the study was obtained from the nursing students after explanation of its aim. 
- Students' right to participate or withdraw from the study was emphasized after reassuring them that their responses would have no impact on their grades.

- Students were re- assured that the collected data would be treated with confidentiality and it would be used only for the purpose of the research.

\section{Statistical tests included:}

Data were coded, computed and analyzed by using SPSS version 16.0. Qualitative variables were presented using descriptive statistics in the form of frequencies \& percentages and $\left(\chi^{2)}\right.$ test was used for comparison. Quantitative variables were presented as means \pm standard deviations and student t test \& F test were used for comparison. Statistical significance was considered at $\mathrm{p}$-value $<0.05$.

\section{Results}

Table (1) shows the characteristics of the studied students. Out of 309 students participated in this study; 82 were in grade I, 97 in grade II, 56 in grade III and 74 in the fourth grade. The student's age ranges from 18 years to more than 22 years, and the average ages significantly differed by grades. The percentage of male students represent one fifth in grade II to one third in grade IV. There is no significant difference between student gender, residence and socio economic status in different grades.

Table (2) shows Frequency distribution of Devaluation discrimination scale (DDS) among studied students. The percentage of items showing signs of discrimination of mental patients is clear like "I will eagerly accept a previous mental patient as my friend" where $60.2 \%$ of studied students respond by not at all and a little. Also, about $68.7 \%$ of the students respond by not at all, a little and some to "I will agree a fully improved previous mental patient as a teacher of young children in a public school". And, about $77.4 \%$ of the students respond by not at all, a little and some to ". I will treat a previous mental patient just as treating anyone".

Table (3) shows Frequency distribution of Social Distance Scale (SDS) among studied students. It assesses respondent's willing to accept people with mental illness. The definitely willing response of the students to accept people of mental illness ranges from $4.2 \%$ to the question "How would you feel about renting a room in your home to a mentally ill patient?" to $14.2 \%$ to the question "How will you feel about recommending a mentally ill patient for a job working with somebody you know?.

Table (4) shows the frequency distribution of Perceptions of Stigmatization by Others for Seeking Help (PSOSH) among studied students. The rate of the student's response as a great deal ranges from $2.6 \%$ to the item "React negatively to them" and $25.6 \%$ to the item "Think bad things of them".

Table (5) shows the Frequency distribution of Self-Stigma of Seeking Help (SSOSH) among studied students. The percentage of the students' response as strongly agrees ranges from $1.3 \%$ (for 4 items of the scale) up to $15.9 \%$ to one item of the scale.

Table (6) shows that there is no significant difference between the average scores of the four scales in different grades.

Table (7) shows the Relationship between socio-demographic characteristics of the studied students and average total scores of the four scales. The average scores of the four scales do not significantly differed by students' age nor residence. Male students show a higher average score of all scales than females but the difference is statistically significant with SDS (P 0.026) and SSOSH scale (P 0.006). The average scores of the scales slightly differed by the level of students' SES and the difference is statistically significant with SDS scale as the students of moderate SES respond with highest average score.

\section{Discussion}

Stigma and discrimination towards patients with mental illness is well reported in literature. There are studies assessing stigma of general public or of some specific groups like university students towards people with mental illness ${ }^{[16]}$. However taking into account the role of mental health professionals in de-stigmatization movement, majority of studies have explored stigma of mental health professionals themselves towards people with mental illness and surprisingly these studies reported that mental health professionals have less optimism and more negative view on long term prognosis of patients with mental illness ${ }^{[17]}$. The current study aimed to assess stigma among undergraduate nursing students through measuring four types of stigma: devaluation discrimination, social distance, cognitive response to people for seeking help and perceptions of other's character for seeking help. In the present study, nursing students have been asked to imagine someone they know who sought treatment with mental illness and to what degree they would react to them, more than half of the studied nursing students think of them in a less favorable way and think they posed a risk to others. This result is in agreement with the findings in studies which had been found negative perceptions about people with schizophrenia among nursing students and the general population, respectively. This is important being as

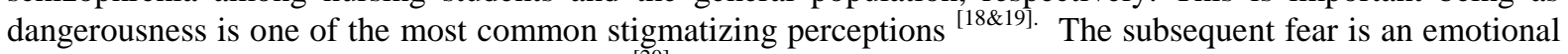
aspect of stigma that can become a prejudice ${ }^{[20]}$. 
In another study it was revealed that the students who label people experiencing the mental disorders as being mentally ill patients are not significantly less ready to interrelate with them. And students are also significantly more likely to think that the people experiencing symptoms of schizophrenia would do something violent toward the others ${ }^{[21]}$.

Majority of studies assessing stigma towards mental illness have adopted the conceptual framework which views mentally ill as lesser and ones requiring coercive handing and social restrictiveness which is considering mentally ill as threat to society, ${ }^{[22 \& 23]}$ and these are consistent with the current study in which more than half of the nursing students represent discriminating behaviors towards patients with mentally illness as they are unwilling to accept a mentally ill patient as a close friend and they view the mentally ill patients as less intelligent than other persons .

In response to social distance, more than half of the nursing students are unwilling to rent a room in their homes to a mental ill patients or working with mentally ill person. In previous research majority of the participants think that people with mental illness are dangerous because of violent behavior and they feel that they get ashamed if people knew someone in their family been diagnosed with mental illness ${ }^{\text {[24] }}$.

The current study revealed that there is no significant difference between stigma and the four grades and this result is inconsistent with previous research indicated that knowledge and attitudes influenced stigmatization. Theories about behavioral change and learning vary as to whether knowledge gained through extrinsic reinforcement such as grads or positive remarks can be sustained in the long term ${ }^{[25]}$.

As regard to the socio-demographic characteristics of the studied students, the present study showed that there is significant difference between student' age and the four scales this may account for the fact that age didn't influence stigma in any of the scales. However male students show higher average score of all scales than female's students and this result is consistent with previous research indicated that male students have more negative overall opinion towards patients with mental illness than female students ${ }^{[26]}$.

\section{Tables}

Table (1): Characteristics of the studied students

\begin{tabular}{|c|c|c|c|c|c|c|c|c|c|c|}
\hline \multirow[t]{2}{*}{ Character } & \multirow[t]{2}{*}{ Item } & \multicolumn{2}{|c|}{ Grade 1 (82) } & \multicolumn{2}{|c|}{ Grade 2 (97) } & \multicolumn{2}{|c|}{ Grade 3 (56) } & \multicolumn{2}{|c|}{ Grade 4 (74) } & \multirow{2}{*}{$\begin{array}{l}\text { Significance } \\
\text { test }\end{array}$} \\
\hline & & No & $\%$ & No & $\%$ & No & $\%$ & No & $\%$ & \\
\hline \multirow[t]{4}{*}{ Age } & $18-19 \mathrm{y}$ & 82 & 100.0 & 66 & 68.0 & 0 & 0.0 & 0 & 0.0 & $\chi^{2}=38.210$ \\
\hline & $20-21 \mathrm{y}$ & 0 & 0.0 & 26 & 26.8 & 55 & 98.2 & 16 & 21.6 & P 0.000 \\
\hline & $22+$ & 0 & 0.0 & 5 & 5.2 & 1 & 1.8 & 58 & 78.4 & \\
\hline & Mean \pm SD & \multicolumn{2}{|c|}{$18.24 \pm 0.43$} & \multicolumn{2}{|c|}{$19.91 \pm 2.24$} & \multicolumn{2}{|c|}{$20.39 \pm 0.53$} & \multicolumn{2}{|c|}{$22.12 \pm 0.76$} & $\mathrm{~F}=108.764$, \\
\hline \multirow[t]{2}{*}{ Sex } & Males & 22 & 26.8 & 19 & 19.6 & 18 & 32.1 & 25 & 33.8 & $\chi^{2}=5.157$ \\
\hline & Females & 60 & 73.2 & 78 & 80.4 & 38 & 67.9 & 49 & 66.2 & P 0.161 \\
\hline \multirow[t]{2}{*}{ Residence } & Rural & 71 & 86.6 & 84 & 86.6 & 48 & 85.7 & 64 & 86.5 & $\chi^{2}=0.029$ \\
\hline & Urban & 11 & 13.4 & 13 & 13.4 & 8 & 14.3 & 10 & 13.5 & P 0.999 \\
\hline \multirow{4}{*}{$\begin{array}{l}\text { Socio } \\
\text { economic } \\
\text { score }\end{array}$} & Very low & 14 & 17.1 & 27 & 27.8 & 10 & 17.9 & 19 & 25.7 & \multirow{4}{*}{$\begin{array}{l}\chi^{2}=8.179 \\
P 0.516\end{array}$} \\
\hline & & 25 & 30.5 & 21 & 21.6 & 11 & 19.6 & 14 & 18.9 & \\
\hline & Moderate & 22 & 26.8 & 28 & 28.9 & 16 & 28.6 & 21 & 28.4 & \\
\hline & High & 21 & 25.6 & 21 & 21.6 & 19 & 33.9 & 20 & 27.0 & \\
\hline
\end{tabular}

Table (2): Frequency distribution of Devaluation discrimination scale (DDS) among studied students (309)

\begin{tabular}{|c|c|c|c|c|c|c|}
\hline Items & Item & $\begin{array}{l}\text { Not At } \\
\text { All }\end{array}$ & $\begin{array}{l}\text { A } \\
\text { Little }\end{array}$ & Some & A Lot & $\begin{array}{l}\text { A Great } \\
\text { Deal }\end{array}$ \\
\hline 1. I will eagerly accept a previous mental patient as my friend. & $\begin{array}{l}\text { No } \\
\%\end{array}$ & $\begin{array}{l}70 \\
22.7\end{array}$ & $\begin{array}{l}116 \\
37.5\end{array}$ & $\begin{array}{l}91 \\
29.4\end{array}$ & $\begin{array}{l}20 \\
6.5\end{array}$ & $\begin{array}{l}12 \\
3.9\end{array}$ \\
\hline $\begin{array}{l}\text { 2. I will consider that a mental ill patient is just as intelligent } \\
\text { as the other persons. }\end{array}$ & $\begin{array}{l}\text { No } \\
\%\end{array}$ & $\begin{array}{l}27 \\
8.7\end{array}$ & $\begin{array}{l}149 \\
48.2\end{array}$ & $\begin{array}{l}86 \\
27.8\end{array}$ & $\begin{array}{l}39 \\
12.6\end{array}$ & $\begin{array}{l}8 \\
2.6\end{array}$ \\
\hline $\begin{array}{l}\text { 3. I think that a previous mental ill patient is just as faith } \\
\text { worthy as the other resident. }\end{array}$ & $\begin{array}{l}\text { No } \\
\%\end{array}$ & $\begin{array}{l}36 \\
11.7\end{array}$ & $\begin{array}{l}79 \\
25.6\end{array}$ & $\begin{array}{l}128 \\
41.4\end{array}$ & $\begin{array}{l}62 \\
20.1\end{array}$ & $\begin{array}{l}4 \\
1.3\end{array}$ \\
\hline $\begin{array}{l}\text { 4. I will agree to a fully improved previous mental patient to } \\
\text { be a teacher of young children in a public school. }\end{array}$ & $\begin{array}{l}\text { No } \\
\%\end{array}$ & $\begin{array}{l}34 \\
11.0\end{array}$ & $\begin{array}{l}77 \\
24.9\end{array}$ & $\begin{array}{l}120 \\
38.8\end{array}$ & $\begin{array}{l}61 \\
19.7\end{array}$ & $\begin{array}{l}17 \\
5.5\end{array}$ \\
\hline $\begin{array}{l}\text { 5. I think that being hospitalized in a mental hospital is an } \\
\text { indication of personal breakdown. }(\mathrm{R})\end{array}$ & $\begin{array}{l}\text { No } \\
\%\end{array}$ & $\begin{array}{l}73 \\
23.6\end{array}$ & $\begin{array}{l}107 \\
34.6\end{array}$ & $\begin{array}{l}80 \\
25.9\end{array}$ & $\begin{array}{l}14 \\
4.5\end{array}$ & $\begin{array}{l}35 \\
11.3 \\
\end{array}$ \\
\hline $\begin{array}{l}\text { 6. I will not accept to employ a previous mental ill patient to } \\
\text { pay attention of my children, even if he or she had been fine } \\
\text { for some time. }(\mathrm{R})\end{array}$ & $\begin{array}{l}\text { No } \\
\%\end{array}$ & $\begin{array}{l}40 \\
12.9\end{array}$ & $\begin{array}{l}91 \\
29.4\end{array}$ & $\begin{array}{l}129 \\
41.7\end{array}$ & $\begin{array}{l}37 \\
12.0\end{array}$ & $\begin{array}{l}12 \\
3.9\end{array}$ \\
\hline $\begin{array}{l}\text { 7. I believe less of a person who has been in a mental hospital. } \\
\text { (R) }\end{array}$ & $\begin{array}{l}\text { No } \\
\%\end{array}$ & $\begin{array}{ll}36 \\
11.7\end{array}$ & $\begin{array}{l}116 \\
37.5\end{array}$ & $\begin{array}{l}97 \\
31.4\end{array}$ & $\begin{array}{ll}56 \\
18.1\end{array}$ & $\begin{array}{ll}4 \\
1.3\end{array}$ \\
\hline $\begin{array}{l}\text { 8. If I were a manager, I would employ a previous mental ill } \\
\text { patient if he is competent for the work. }\end{array}$ & $\begin{array}{l}\text { No } \\
\%\end{array}$ & $\begin{array}{ll}43 \\
13.9\end{array}$ & $\begin{array}{ll}68 \\
22.0\end{array}$ & $\begin{array}{l}105 \\
34.0\end{array}$ & $\begin{array}{l}71 \\
23.0\end{array}$ & $\begin{array}{l}22 \\
7.1\end{array}$ \\
\hline $\begin{array}{l}\text { 9. If I were a manager, I would refuse the applicant of a } \\
\text { previous mental patient in good turn of another applicant. (R) }\end{array}$ & $\begin{array}{l}\text { No } \\
\%\end{array}$ & $\begin{array}{l}55 \\
17.8 \\
\end{array}$ & $\begin{array}{l}91 \\
29.4 \\
\end{array}$ & $\begin{array}{l}82 \\
26.5 \\
\end{array}$ & $\begin{array}{l}53 \\
17.2 \\
\end{array}$ & $\begin{array}{l}28 \\
9.1\end{array}$ \\
\hline $\begin{array}{l}\text { 10. I will treat a previous mental patient just as treating } \\
\text { anybody. }\end{array}$ & $\begin{array}{l}\text { No } \\
\%\end{array}$ & $\begin{array}{ll}56 \\
18.1\end{array}$ & $\begin{array}{l}88 \\
28.5\end{array}$ & $\begin{array}{l}95 \\
30.7\end{array}$ & $\begin{array}{l}44 \\
14.2\end{array}$ & $\begin{array}{l}26 \\
8.4\end{array}$ \\
\hline
\end{tabular}


Stigma in Nursing Students towards Patients with Mental Illness

\begin{tabular}{|l|l|l|l|l|l|}
\hline $\begin{array}{l}\text { 11. I will be unwilling to meeting a person who has been } \\
\text { hospitalized in a mental hospital for a severe psychiatric } \\
\text { disease. (R) }\end{array}$ & $\begin{array}{l}\text { No } \\
\%\end{array}$ & $\begin{array}{l}43 \\
13.9\end{array}$ & $\begin{array}{l}120 \\
38.8\end{array}$ & $\begin{array}{l}95 \\
30.7\end{array}$ & $\begin{array}{l}47 \\
15.2\end{array}$ \\
\hline $\begin{array}{l}\text { 12. If I know a person in a psychiatric hospital, the majority of } \\
\text { people will get his or her opinions less gravely. (R) }\end{array}$ & $\begin{array}{l}\text { No } \\
\%\end{array}$ & $\begin{array}{l}58 \\
18.8\end{array}$ & \begin{tabular}{l}
19.1 \\
\hline
\end{tabular} & $\begin{array}{l}122 \\
39.5\end{array}$ & 45 \\
\hline
\end{tabular}

Table (3): Frequency distribution of Social Distance Scale (SDS) among studied students (309)

\begin{tabular}{|c|c|c|c|c|c|}
\hline Items & Item & $\begin{array}{l}\text { Definitely } \\
\text { Unwilling }\end{array}$ & $\begin{array}{l}\text { Probably } \\
\text { Unwilling }\end{array}$ & $\begin{array}{l}\text { Probably } \\
\text { Willing }\end{array}$ & $\begin{array}{l}\text { Definitely } \\
\text { Willing }\end{array}$ \\
\hline $\begin{array}{l}1 \text {.How will you feel about renting a room in your home to a } \\
\text { mentally ill patient? }\end{array}$ & $\begin{array}{l}\text { No } \\
\%\end{array}$ & $\begin{array}{l}120 \\
38.8\end{array}$ & $\begin{array}{l}77 \\
24.9\end{array}$ & $\begin{array}{l}99 \\
32.0\end{array}$ & $\begin{array}{l}13 \\
4.2\end{array}$ \\
\hline $\begin{array}{l}\text { 2. How will you feel about working with a mentally ill } \\
\text { patient? }\end{array}$ & $\begin{array}{l}\text { No } \\
\%\end{array}$ & $\begin{array}{l}20 \\
6.5\end{array}$ & $\begin{array}{l}154 \\
49.8\end{array}$ & $\begin{array}{l}116 \\
37.5\end{array}$ & $\begin{array}{l}19 \\
6.1\end{array}$ \\
\hline $\begin{array}{l}\text { 3. How will you feel about having a mentally ill patient to be } \\
\text { your neighbor? }\end{array}$ & $\begin{array}{l}\text { No } \\
\%\end{array}$ & $\begin{array}{ll}47 \\
15.2\end{array}$ & $\begin{array}{l}85 \\
27.5\end{array}$ & $\begin{array}{l}147 \\
47.6\end{array}$ & $\begin{array}{l}30 \\
9.7\end{array}$ \\
\hline $\begin{array}{l}\text { 4. How will you feel about having a mentally ill patient to } \\
\text { take care of your children? }\end{array}$ & $\begin{array}{l}\text { No } \\
\%\end{array}$ & $\begin{array}{l}76 \\
24.6\end{array}$ & $\begin{array}{l}124 \\
40.1\end{array}$ & $\begin{array}{l}70 \\
22.7\end{array}$ & $\begin{array}{l}39 \\
12.6\end{array}$ \\
\hline $\begin{array}{l}\text { 5. How will you feel about having your children marry } \\
\text { someone with a mental illness? }\end{array}$ & $\begin{array}{l}\text { No } \\
\%\end{array}$ & $\begin{array}{l}71 \\
23.0\end{array}$ & $\begin{array}{l}112 \\
36.2\end{array}$ & $\begin{array}{l}103 \\
33.3\end{array}$ & $\begin{array}{l}23 \\
7.4\end{array}$ \\
\hline $\begin{array}{l}\text { 6. How will you feel about introducing a mentally ill patient } \\
\text { to your close friends? }\end{array}$ & $\begin{array}{l}\text { No } \\
\%\end{array}$ & $\begin{array}{l}51 \\
16.5\end{array}$ & $\begin{array}{ll}96 \\
31.1\end{array}$ & $\begin{array}{l}121 \\
39.2\end{array}$ & $\begin{array}{ll}41 \\
13.3\end{array}$ \\
\hline $\begin{array}{l}\text { 7. How would you feel about recommending a mentally ill } \\
\text { patient to work with someone you know? }\end{array}$ & $\begin{array}{l}\text { No } \\
\%\end{array}$ & $\begin{array}{l}55 \\
17.8\end{array}$ & $\begin{array}{l}63 \\
20.4\end{array}$ & $\begin{array}{l}147 \\
47.6\end{array}$ & $\begin{array}{l}44 \\
14.2\end{array}$ \\
\hline
\end{tabular}

Table (4): Frequency distribution of Perceptions of Stigmatization by Others for Seeking Help (PSOSH) among studied students (309)

\begin{tabular}{|cl|l|l|l|l|l|l|}
\hline Items & & Item & $\begin{array}{l}\text { Not At } \\
\text { All }\end{array}$ & $\begin{array}{l}\text { A } \\
\text { Little }\end{array}$ & Some & $\begin{array}{l}\text { A Lot } \\
\text { A Great } \\
\text { Deal }\end{array}$ \\
\hline $1-$ & Respond pessimistically to them. & No & 133 & 91 & 71 & 6 & 8 \\
& & $\%$ & 43.0 & 29.4 & 23.0 & 1.9 & 2.6 \\
\hline $2-$ & Think bad things of them & No & 8 & 29 & 92 & 101 & 79 \\
& & $\%$ & 2.6 & 9.4 & 29.8 & 32.7 & 25.6 \\
\hline $3-$ & See them as seriously disturbed & No & 70 & 97 & 91 & 34 & 17 \\
& & $\%$ & 22.7 & 31.4 & 29.4 & 11.0 & 5.5 \\
\hline $4-$ & Think of them in a less positive way & No & 14 & 37 & 50 & 139 & 69 \\
& & $\%$ & 4.5 & 12.0 & 16.5 & 45.0 & 22.3 \\
\hline $5-$ & Think they posed a risk to others. & No & 27 & 35 & 84 & 107 & 56 \\
& & $\%$ & 8.7 & 11.3 & 27.2 & 34.6 & 18.1 \\
\hline
\end{tabular}

Table (5): Frequency distribution of Self-Stigma of Seeking Help (SSOSH) among studied students (309)

\begin{tabular}{|c|c|c|c|c|c|c|}
\hline Items & Item & $\begin{array}{l}\text { Strongly } \\
\text { disagree }\end{array}$ & Disagree & Neutral & Agree & $\begin{array}{l}\text { Strongly } \\
\text { agree }\end{array}$ \\
\hline $\begin{array}{l}\text { 3- I will feel they are less intelligent if they require } \\
\text { psychological help. }\end{array}$ & $\begin{array}{l}\text { No } \\
\%\end{array}$ & $\begin{array}{ll}41 \\
13.3\end{array}$ & $\begin{array}{l}127 \\
41.1\end{array}$ & $\begin{array}{l}100 \\
32.4\end{array}$ & $\begin{array}{l}6237 \\
12.0\end{array}$ & $\begin{array}{ll}4 \\
1.3\end{array}$ \\
\hline $\begin{array}{l}\text { 5-My feel of them will not change just because they make the } \\
\text { choice to visit a psychotherapist. (R) }\end{array}$ & $\begin{array}{l}\text { No } \\
\%\end{array}$ & $\begin{array}{l}55 \\
17.8 \\
\end{array}$ & $\begin{array}{l}76 \\
24.6\end{array}$ & $\begin{array}{l}95 \\
30.7\end{array}$ & $\begin{array}{l}40 \\
12.9\end{array}$ & $\begin{array}{l}43 \\
13.9\end{array}$ \\
\hline $\begin{array}{l}\text { 6-I will not think they are inferior because they just ask a } \\
\text { therapist for help. }\end{array}$ & $\begin{array}{l}\text { No } \\
\%\end{array}$ & $\begin{array}{ll}41 \\
13.3\end{array}$ & $\begin{array}{ll}65 \\
21.0\end{array}$ & $\begin{array}{l}135 \\
43.7\end{array}$ & $\begin{array}{l}46 \\
14.9\end{array}$ & $\begin{array}{l}22 \\
7.1\end{array}$ \\
\hline $\begin{array}{l}\text { 7- If they decide to look for psychological support, I will } \\
\text { believe satisfactory about them. (R) }\end{array}$ & $\begin{array}{l}\text { No } \\
\%\end{array}$ & $\begin{array}{l}15 \\
4.9\end{array}$ & $\begin{array}{l}90 \\
29.1\end{array}$ & $\begin{array}{ll}88 \\
28.5\end{array}$ & $\begin{array}{l}92 \\
29.8\end{array}$ & $\begin{array}{l}24 \\
7.8\end{array}$ \\
\hline $\begin{array}{l}\text { 10- If they could not resolve their own psychological } \\
\text { problems I will feel inferior about them. }\end{array}$ & $\begin{array}{l}\text { No } \\
\%\end{array}$ & $\begin{array}{l}36 \\
11.7\end{array}$ & $\begin{array}{l}91 \\
29.4\end{array}$ & $\begin{array}{l}81 \\
26.2\end{array}$ & $\begin{array}{l}93 \\
30.1\end{array}$ & $\begin{array}{l}8 \\
8\end{array}$ \\
\hline
\end{tabular}

Table (6): Comparison of the average total scores of the four scales among students of different academic years

\begin{tabular}{|l|l|l|l|l|l|}
\hline Academic year & \multirow{2}{*}{ No } & DDS & SDS & PSOSH & SSOSH \\
\cline { 3 - 6 } & & Mean \pm SD & Mean \pm SD & Mean \pm SD & Mean \pm SD \\
\hline First & 82 & $32.21 \pm 6.57$ & $16.63 \pm 3.42$ & $15.05 \pm 2.07$ & $28.26 \pm 3.91$ \\
\hline Second & 97 & $31.41 \pm 6.43$ & $16.30 \pm 3.52$ & $15.07 \pm 2.04$ & $27.51 \pm 3.95$ \\
\hline Third & 56 & $31.57 \pm 6.89$ & $16.95 \pm 3.70$ & $15.46 \pm 1.79$ & $28.43 \pm 4.18$ \\
\hline Fourth & 74 & $31.19 \pm 6.67$ & $16.39 \pm 3.62$ & $15.20 \pm 1.95$ & $27.75 \pm 4.01$ \\
\hline
\end{tabular}




\begin{tabular}{|l|l|l|l|l|l|}
\hline Significance test & $\mathrm{F}$ & 0.362 & 0.454 & 0.598 & 0.885 \\
& $\mathrm{P}$ & 0.788 & 0.715 & 0.617 & 0.449 \\
\hline
\end{tabular}

Table (7): Relationship between socio-demographic characteristics of the studied students and average total scores of the four scales

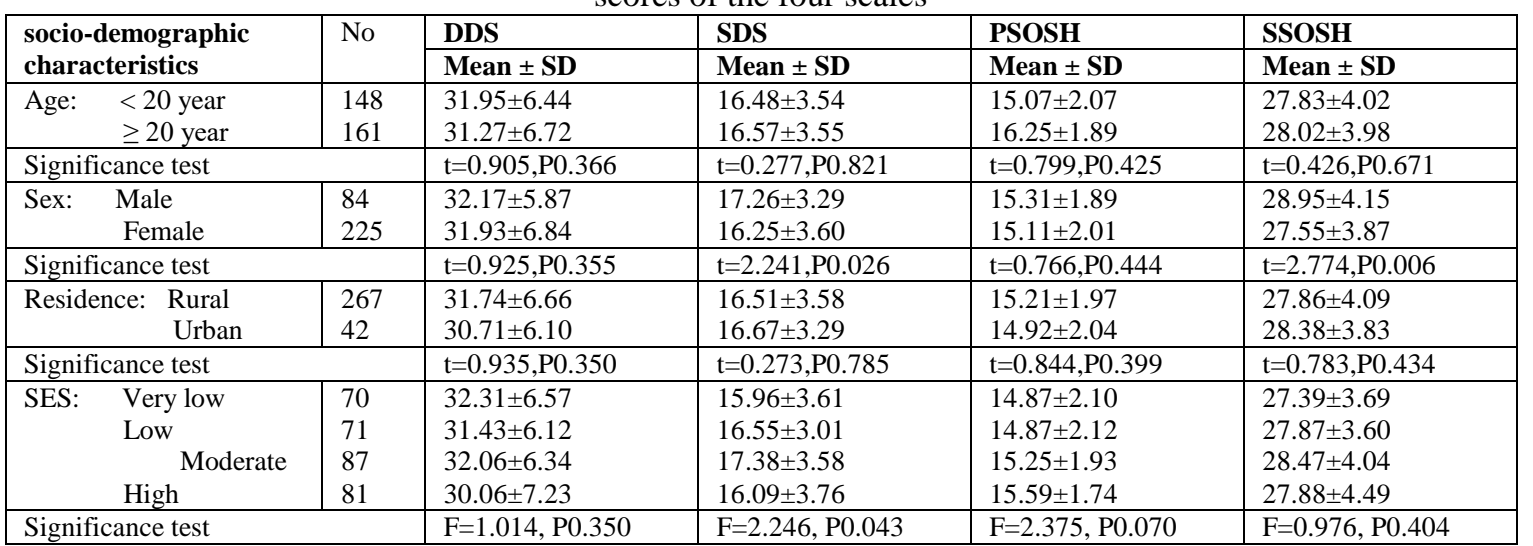

\section{Conclusion And Recommendations}

The present study revealed that stigma is common among nursing students; also the results showed that there is no difference in stigma toward patients with mental illness among nursing students in different grades. On that base, it is recommended to reorient the education system in such a way that during learning psychiatric nursing course, issue like stigma is also effectively dealt with. Future research is needed in hope of recognizing the best way to alter stigma towards mental illness.

\section{Acknowledgment}

The researcher would like to thank the nursing students in the Faculty of Nursing, Mansoura

University, Egypt who accepted to participate in this research.

\section{Reference}

[1]. Ahmedani, B. K. (2011). Mental Health Stigma: Society, Individuals, and the Profession. Journal of Social Work Values and Ethics, 8(2), 41-416. Retrieved from http://www.ncbi.nlm.nih.gov/pubmed/22211117

[2]. Ghai, S., Sharma, N., Sharma, S., \& Kaur, H. (2013). Shame and stigma of mental illness. Delhi Psychiatric Journal.

[3]. Angermeyer, M. C., \& Matschinger, H. (2004). The stereotype of schizophrenia and its impact on discrimination against people with schizophrenia: results from a representative survey in Germany. Schizophrenia Bulletin, 30(4), 1049-1061.

[4]. McDaid, D. (2008). Countering the stigmatisation and discrimination of people with mental health problems in Europe. European Commission, 1-20. Retrieved from http://sid.usal.es/idocs/F8/FDO23165/estigma_enfer_mental.pdf

[5]. Svensson, B., Brunt, D., Bejerholm, U., Eklund, M., Gyllensten, A. L., Leufstadius, C., ... Hansson, L. (2014). Health Care Students 'Attitudes towards People with Schizophrenia - A Survey of Eight University Training Programs, (October), 309-316.

[6]. Hugo, M. (2001). Mental health professionals' attitudes towards people who have experienced a mental health disorder. Journal of Psychiatric and Mental Health Nursing, 8(5), 419-425.

[7]. Poreddi, V., Thimmaiah, R., \& Math, S. B. (2015). Attitudes toward people with mental illness among medical students. Journal of Neurosciences in Rural Practice, 6(3), 349-354. http://doi.org/10.4103/0976-3147.154564

[8]. Hunter, L., Weber, T., Shattell, M., \& Harris, B. A. (2015). Nursing Students' Attitudes about Psychiatric Mental Health Nursing. Issues in Mental Health Nursing, 36(1), 29-34. http://doi.org/10.3109/01612840.2014.935901

[9]. Happell, B., Robins, A., \& Gough, K. (2008). Developing more positive attitudes towards mental health nursing in undergraduate students: part 2--The impact of theory and clinical experience. Journal of Psychiatric and Mental Health Nursing, 15(7), 527-536. http://doi.org/10.1111/j.1365-2850.2007.01233.x

[10]. Thompson, S.K. 1987. Sample Size for Estimating Multinomial Proportions Proportions. The American Statistician. American Statistical Association, U.S.A. 41(1), 42-46.

[11]. El-Gilany, A., El-Wehady, A., \& El-Wasify, M. (2012). Updating and validation of the socioeconomic status scale for health research in Egypt. Eastern Mediterranean Health Journal = La Revue de Sante de La Mediterranee Orientale = Al-Majallah AlSihhiyah Li-Sharq Al-Mutawassit, 18(9), 962-968.

[12]. Link, B. G., Yang, L. H., Phelan, J. C., \& Collins, P. Y. (2004). Measuring mental illness stigma. Schizophrenia Bulletin, 30(3), 511-541. http://doi.org/10.1093/oxfordjournals.schbul.a007098

[13]. Penn, D. L., Guynan, K., Daily, T., Spaulding, W. D., Garbin, C. P., \& Sullivan, M. (1994). Dispelling the Stigma of Schizophrenia: What Sort of Information Is Best? Schizophrenia Bulletin, 20(3), 567-578. Retrieved from http://dx.doi.org/10.1093/schbul/20.3.567

[14]. Vogel, D. L., Wade, N. G., \& Ascheman, P. L. (2009). Measuring perceptions of stigmatization by others for seeking psychological help: Reliability and validity of a new stigma scale with college students. Journal of Counseling Psychology, 56(2), 301-308. http://doi.org/10.1037/a0014903

[15]. Vogel, D. L., Wade, N. G., \& Haake, S. (2006). Measuring the self-stigma associated with seeking psychological help. Journal of Counseling Psychology, 53(3), 325-337. http://doi.org/10.1037/0022-0167.53.3.325

[16]. Dessoki H H, Hifnawy T. Beliefs about mental illness among university students in Egypt. Eur J Psychology $2009 ; 1$ : 1- 19.

[17]. Lauber C, Anthony M, Ajdacio-Gross V\& Rossler W. What about psychiatrists' attitude to mentally ill people?. Euro Psychiatry $2004 ; 19$ (7): 423-27. 
[18]. Bjorkman, T., Svensson, B., \& Lundberg, B. (2007). Experiences of stigma among people with severe mental illness. Reliability, acceptability and construct validity of the Swedish versions of two stigma scales measuring devaluation/discrimination and rejection experiences. Nordic Journal of Psychiatry, 61(5), 332-338. http://doi.org/10.1080/08039480701642961

[19]. CRISP, A. H., GELDER, M. G., RIX, S., MELTZER, H. I., \& ROWLANDS, O. J. (2000). Stigmatisation of people with mental illnesses. The British Journal of Psychiatry, 177(1), 4 LP-7. Retrieved from http://bjp.rcpsych.org/content/177/1/4.abstract

[20]. Matchinger H, Dietrich S, Angermeyer MC. the relationship between biogenetic causal explanations and social distance towards people with mental disorders: Results from a population survey in Germany. International journal of social psychiatry. 2006; 52(2): 166-74.

[21]. Hill, J. (2005). Attitudes Toward Mental Disorders Among College Students. Journal of Undergraduate Research, 15, 1-8.

[22]. Al-Awadhi, A., Atawneh, F., Alalyan, M. Z., Shahid, A., Al-Alkhadhari, S., \& Zahid, M. (2017). attitude towards patients with mental illness in a general hospital in Kuwait. Saudi Journal of Medicine and Medical Sciences, 5(1), 31-37. http://doi.org/10.4103/1658-631X.194249

[23]. Reta, Y., Tesfaye, M., Girma, E., Dehning, S., \& Adorjan, K. (2016). Public Stigma against People with Mental Illness in Jimma Town, Southwest Ethiopia. PLOS ONE, 11(11), e0163103. Retrieved from http://dx.doi.org/10.1371\%2Fjournal.pone.0163103

[24]. Ghanean, H. (2013). Studies on the perception of mental illness and epilepsy in Tehran, Iran.

[25]. Korthagen FAJ. Situated learning theory and pedagogy of teatcher education: Towards an integrated view of teacher behavior and teacher learning. Teacher and Teacher Education. 2010; 26: 98-106

[26]. Gelder, M., Crisp, A., Goddard, E., Meltzer, H. Stigmatization of people with mental illness: a follow-up study within the changinng minds campaign of the royal college of psychiatris. World psychiatry. 2005; 4 (2): 106-13 